\title{
3 Trans-ing gender boundaries and national borders
}

\author{
Rethinking identity in Merzak \\ Allouache's Chouchou (2003) \\ and Angelina Maccarone's Fremde \\ Haut/Unveiled (2005)
}

\section{C.L. Quinan}

Taking as its point of departure the ways in which sexualities are produced through and in relation to migration, including how the nation-state as a heteronormative institution upholds hierarchies of sexuality, race, gender, and class, queer migration studies has honed in on the structures that underlie the production of social inequalities and has offered insight into how access to transnational migration is differentially distributed (Phelan 2001; Luibhéid 2002; Luibhéid and Cantú Jr. 2005). Despite these crucial interventions, this body of work has underestimated the degree to which conforming to binary gender norms shapes possibilities for - and experiences of - mobility, citizenship, and inclusion. Scholarship in the field of trans studies, has, however, begun to fill this gap by analysing tensions between migration and belonging (Cotten 2012; Aizura 2012; Bhanji 2013). Indeed, the boundary-crossing potentialities of trans approaches attentive to mobility and movement make them especially relevant to analyses of migration. Moreover, the grammatically multifarious word 'trans' also participates in linguistic border-crossings: 'It can be a noun as well as a prefix that attaches to and dynamises other words, providing new directions for them', as Karine Espineira and Marie-Hélène/Sam Bourcier point out (Espineira and Bourcier 2016: 90). Unlike the English-centric 'queer', 'Trans works as well in French, Spanish, Italian, and many other languages as it does in English. What are we to make of the mobility of this little unit of grammar, its ability to animate, to cross?' (Espineira and Bourcier 2016: 90).

This chapter grapples with this question from a conceptual standpoint and asks how we might theorise intersections between migration and nonnormative genders and sexualities in European postcolonial cinema. Starting from the premise that conceiving of trans as a mode of analysis in these ways yields productive insights into the literal and metaphoric aspects of migration and borders, this chapter analyses trans as movement in two films: Merzak Allouache's 2003 French-language comedy Chouchou (France), and Angelina Maccarone's 2005 German-language drama Fremde Haut/Unveiled 
(Germany/Austria). Allouache's commercially successful comedy introduces us to a transgender North African migrant who arrives in France (disguised as a Chilean male asylum seeker fleeing Pinochet's regime) and soon begins to both present and identify as a woman, while Maccarone's drama tells the story of an Iranian female who flees to Germany due to persecution for her queer relationship, but later takes on the identity of a male acquaintance with papers in order to stay in the country. In reflecting yet also distorting the contemporary social and political climate of non-European migrants arriving to Europe, the two films 'trans' - that is surpass, transcend, and cross notions of gender, genre, nation, and migration. While negotiating multiple border-crossings, the films' migrant outsiders prompt us to interrogate what happens not only when we queer but also when we trans migration. That is, what do we notice when we look to those whose experiences of traversing national borders is tied up in a crossing of gender boundaries?

Both films engage with the contemporary nexus of migration and displacement, and probe tensions between hospitality and hostility that continue to mark the postcolonial European metropole - tensions that are particularly salient for queer and trans migrants. ${ }^{1}$ Although Chouchou and Fremde Haut predate the most recent (and ongoing) European refugee 'crisis' in which many migrants are met with a hopeless - if not deathly - situation en route to European sea and land borders, they showcase the complex negotiations that have long faced migrants of colour in gaining entry into Fortress Europe. These challenges are further exacerbated by the protagonists' gender transgressions, queer sexualities, and non-Western backgrounds.

While this chapter could easily focus on the queer potentials that both Allouache's and Maccarone's films showcase, I instead want to emphasise the possibilities that a trans analysis might hold in analysing overlapping processes of transnational and transgender assimilation, exclusion, and aggregation. ${ }^{2}$ In this sense, the films prompt similar questions around transgender, transnational, and transcultural experiences. Together, they have something to say about the place of gender queerness in experiences of migration, exile, diaspora, and displacement - thematics that have only begun to be depicted in postcolonial and migrant cinema. ${ }^{3}$

\section{Fremde Haut/Unveiled}

Fremde Haut is the second feature-length film from writer and director Angelina Maccarone, who was born in Germany in 1965 to an Italian guest worker. The film received numerous awards, most notably at the Montreal Gay and Lesbian Film Festival and the Seattle Lesbian and Gay Film Festival. Before turning to the film's plot, it is worth noting the ambiguity of its title. While the U.S.-based distributor retitled it Unveiled (which plays upon ideas of visibility and invisibility and Arab femininity), the German Fremde Haut has a double-meaning that is lost in its anglicised transformation. Literally translated as 'foreign skin' or 'stranger's skin', the metaphorical meaning of 


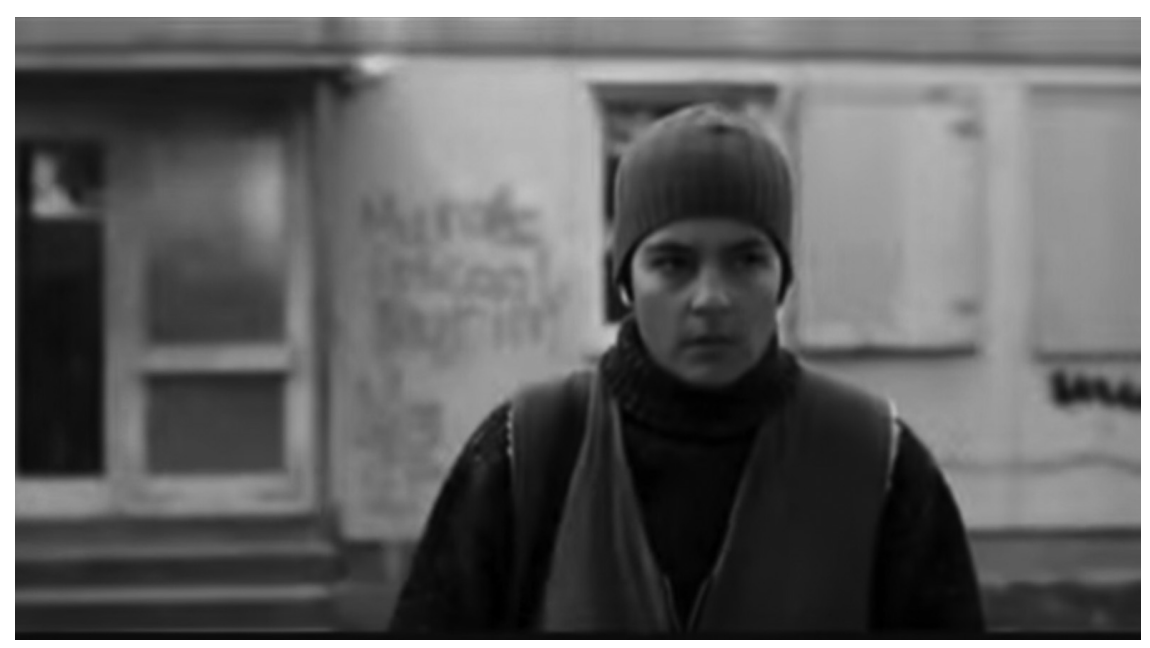

Figure 3.1 Fariba/Siamak (Jasmin Tabatabai) in Fremde Haut/Unveiled (2005)

Source: Unveiled/Fremde Haut (2005), directed by Angelina Maccarone @ Fischer Film, MM Zimmermann \& Co, and Millivres Multimedia (2007).

the German 'fremde Haut' signifies 'in orbit', a term that is also used in the U.N.'s description of asylum seekers. Jack Halberstam elaborates: 'Asylum seekers are spoken about as "fremde Haut" or "in orbit" . . . because they can actually find legal domicile nowhere at all... [T] his notion, of asylum seekers as "in orbit", as lost in space or in perpetual motion frames the film quite differently than the English title' (Halberstam 2012: 349-50). The title's reduction to 'unveiled' obscures the double meaning of 'fremde Haut', which emphasises the film's thematic threads: the body - the skin - as well as the perpetual motion, in-betweenness, and transition of the main character.

Just as the multivalent title suggests, there is a thematic thread of movement and its relationship to gender and borders running through the film, which the viewer is met with at the immediate outset. The film opens inside a plane, with the pilot indicating over the loudspeaker that they have just left Iranian airspace, an announcement that prompts some women to remove their head scarves. We are soon introduced to one of the flight's passengers, Fariba Tabrizi (played by Jasmin Tabatabai), an Iranian female who flees Iran when her relationship with Shirin, a married woman, is discovered. Fariba arrives in Germany and is forced to stay in a refugee holding centre at the Frankfurt airport with other asylum seekers. Among them is Siamak, a young political activist, who is also from Iran. Fariba never reveals to the German authorities her actual reason for requesting asylum (i.e., that her life was in jeopardy because of her queerness), only saying she was condemned to death for political reasons. Although persecution based on sexual 
orientation and now gender identity is grounds for possible asylum, it has been notoriously difficult for sexual and gender minorities to 'prove' their sexuality or gender and their persecution. They must abide by normative scripts that rely on Western constructions of gender and sexuality and on static notions of sexual orientation as 'true', inherent, and unchanging. For these reasons, those seeking asylum on such grounds are overwhelmingly denied. In this context, Fariba is not willing to participate in the generation of a colonialist script that orientalises her home country and pinkwashes Germany, her host nation. She is also unwilling to follow a linear narrative of 'lesbian' normativity to gain refugee status.

Consequently, her application is denied, but before being sent back to Iran, she discovers that Siamak's application to temporarily stay is granted. However, out of feelings of hopelessness, he kills himself. Fariba is the first to discover his body and makes the split-second decision to take on his identity in order to use his temporary permit. Now required to present as male and pass as Siamak, the protagonist is sent to a rural town near Stuttgart. Although restricted from movement or employment, Fariba/Siamak secures an under-the-table job at a sauerkraut factory, where he is met with a number of violent racist and xenophobic encounters, both verbal and physical. ${ }^{4}$ There, he also develops a relationship with co-worker Anne, who begins to learn Siamak's true identity. Eventually, German immigration officials inform Siamak that he must leave Germany, for, given the changing political climate in Iran, it is purportedly now safe to return home. This development then prompts the protagonist to tell Anne the full story and they devise a plan that will allow Siamak/Fariba to flee using a fake passport. Soon after, however, Anne's friends come to her house where they discover that Siamak is Fariba, a revelation that causes them to violently attack her. This has devastating consequences, for the police are called and Fariba is promptly deported. The film ends with another gender transition, for on the plane back to Tehran the protagonist disposes of Fariba's passport in the plane's lavatory but keeps Siamak's and now presents as male, leaving the viewer to wonder what the future holds for the protagonist.

Rather than presenting a narrative that equates westward migration with freedom and acceptance, Fremde Haut instead critiques German attitudes towards foreigners and European asylum policies and procedures. Writerdirector Maccarone stated that she was committed to making this film reflect the real-life experiences of persecuted sexual minorities seeking asylum in Europe. In her words:

I become furious when I see how the border between 'us' and 'them' is firmly cemented in the majority of images one sees. 'We' sit in front of the TV and watch as 'they' attempt to gain entry to Fortress Europe.

(cited in Lewis 2016: 129)

Putting forth a clear commentary on European attitudes towards gender and sexual minorities, the film forces us to ask: even if homosexuality is 
criminalised in Iran, is Germany's treatment of LGBTIQ+ identifying individuals - as well as non-Western groups more broadly - any better?

\section{Chouchou}

Addressing similar themes, such as sexual citizenship, containment, and resistance, Chouchou is a narrative of sexual and gender otherness and transnational migration. However, unlike the more independently produced Fremde Haut, Chouchou - by virtue of its status as a blockbuster comedy - operates within a mainstream generic framework. In contrast to the growing focus in feature films and documentaries on realistic portrayals of those seeking asylum in Europe, Chouchou presents a near-farcical take on migration, and this time from a former colony (Algeria) to the metropole (France). Just as Fremde Haut opens with a plane crossing the invisible border of Iranian airspace, Chouchou begins with two images of transport, similarly showing its immediate interest in mobility, transportation, and crossing over. But the highly protected borders of Fortress Europe are conspicuously absent here as the protagonist disembarks from a boat in Marseille and then alights from a train in Paris. Here we see no signs of border control or detention centres. While Fremde Haut's realism lent itself to a more overt commentary on European xenophobia, homophobia, and transphobia, Chouchou is, on the whole, so outlandish that, as I suggest later, we read it as an underhand critique of French attitudes towards gender minorities and North African migrants.

Chouchou was directed by the highly successful filmmaker Merzak Allouache, who has been credited with the emergence of a new wave of Algerian cinema dealing with questions of gender and sexuality. Born in Algeria in 1944, Allouache has made 18 films to date (including fiction and documentary) and maintains a presence within both the French and Algerian film industries. His body of work is politically motivated and is shaped by the colonial/postcolonial relationship between France and Algeria, which, as Will Higbee has noted, is grounded in 'reinterpreting "official" versions of France's and Algeria's colonial past, while also challenging reductive stereotypes of France's North African immigrant population found in the nation's postcolonial present' (Higbee 2007: 6). Chouchou builds upon this trajectory in its comedic take on the experiences of an undocumented Algerian immigrant, played by well-known actor and comedian Gad Elmaleh. The comedy tells the story of Choukri, nicknamed 'Chouchou', an Algerian transgender individual who has arrived in Paris presenting as male but soon self-identifies as female. ${ }^{5}$ Humour begins at the outset, as Chouchou has come dressed in clothing that we would most likely associate with South American indigenous communities. This outfit borders on the ridiculous, but we soon learn that Chouchou is claiming to be a Chilean asylum seeker fleeing Pinochet's dictatorial regime, anachronistic as that may be given the 'temporal drag' (Freeman 2010) between that historical moment and the present day. 


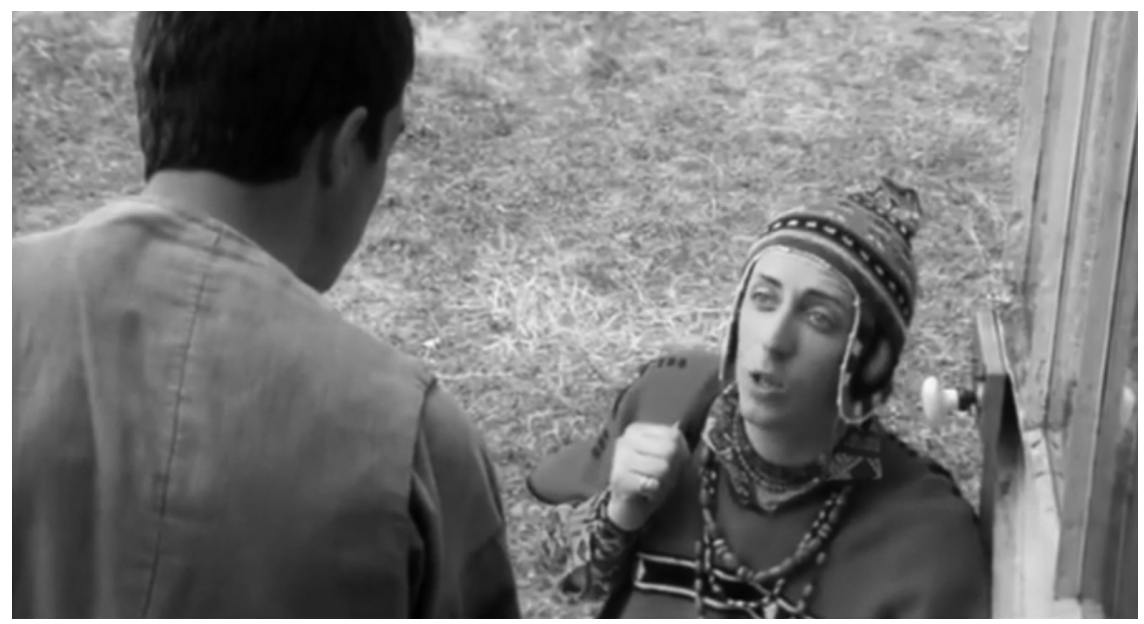

Figure 3.2 Chouchou (Gad Elmaleh) arriving in Paris in Chouchou (2003)

Source: Chouchou (2003), directed by Merzak Allouache (C) France 2 Cinéma, Fechner Productions, KS2 Productions, and Warner Home Video France (2002).

Unlike Fariba in Fremde Haut, this narrative of victimhood that Chouchou creates may allow for refuge in France. As Mireille Rosello (2011) has pointed out, there are clear reasons why Chouchou would have chosen to take on the identity of a Chilean asylum seeker, as it shifts any sort of potential blame or guilt for a colonial past from the French on to another. Hence, France can emerge as hospitable. However, the narrative is so far-fetched that it is illegible and preposterous and so exceedingly utopic that we can only find the film to be a critique of French views towards the Other, both gender and migrant.

Attempting to find a place to stay, Chouchou ends up being taken in by two Catholic priests who are not convinced by the story but say that they do not need to know the reasons why Chouchou has ended up here in this small Parisian suburb. Eventually Chouchou gets a job as assistant to a psychoanalyst who, like the priests, is overwhelmingly accepting. In fact, it is here that we learn of Chouchou's sexuality and gender identity, for she quickly opens up to her boss, confessing 'I never had problems with homosexuality, but my real dream is to become a woman'. The therapist then insists that henceforth Chouchou come to work as a woman and will be treated as such in her office. Later on, Chouchou emerges from the Place de Clichy metro stop in Paris and has a chance encounter with Djamila, a trans friend from Algeria who has also migrated to France. Through Djamila, Chouchou is introduced to The Apocalypse, a nightclub primarily populated by drag queens, trans women, and gay men. There, Chouchou meets a wealthy man named Stanislas, with whom she falls in 
love. Nothing seems to be an obstacle to this coupling of a bourgeois white French man and a transgender Algerian immigrant.

That is, until Inspector Grégoire, a police officer and former patient of Chouchou's boss, creates problems, for he sees Chouchou as standing in his way of seeing the therapist. His behaviour towards her is aggressive (if also comic), but this is not because of her perceived gender or sexual orientation. Instead, he targets Chouchou's migration status, threatening to deport her and separate her from Stanislas. Before long, Grégoire's higherups effectively save her when they realise that she is being targeted by their colleague. (The viewer can imagine this rescue narrative is far from reality, as there exists a long history of North African migrants being racially profiled and targeted for deportation by law enforcement in France.) In a sense, the institution of law enforcement actually 'fails' here in allowing this undocumented migrant to remain in France, thereby opening up queer kinship possibilities. Chouchou will no longer be torn from her lover, and they can pursue their hopes of being married with the community's blessing.

Under the comic surface, we can find a clear critique of France which, upon closer analysis, actually emerges as hostile to both gender nonnormativity and migrant outsiderness. It is through the film's genre as slapstick comedy and exaggerated acceptance of difference that we realise that this story cannot be taken at face-value. For instance, the priest and psychotherapist - symbolic of religion and mental health - are uncharacteristically understanding, while the police inspector is clearly hostile, but not because of Chouchou's gender presentation but because she 'blocks' him from seeing the therapist. Not only has the Catholic Church been historically intolerant of non-reproductive couplings, but psychotherapy has long been the gatekeeper of gender transition, restricting personal freedom and doing extreme violence to some trans people (if not also allowing others access to social and medical services).

The film's final scene further underlines the hidden critique. Chouchou and Stanislas jubilantly run towards one other, Chouchou decked out in a white wedding dress and Stanislas dressed in a dapper suit. We cannot help but smile - not only because Stanislas trips on the way, but also because it utilises the comic tool of filming in slow-motion. While some scholars have critiqued this final scene as being unrealistic, I argue that it is precisely this vision of a utopian vision of a multicultural France wherein different ages, races, and classes commingle (including Stanislas's high-class parents and Chouchou's community of gender-diverse Algerian migrants) to celebrate the marriage of a French bourgeois man and a transgender Algerian woman, blessed by a Catholic priest no less, that signals Allouache's final wink at the viewer. Comedy here serves a role in forcing us to return to the beginning of the film and read it as a critique of French policies related to migration, gender, and sexuality.

Certainly, Allouache would have also been aware of the contemporary growing ascendancy of the far-right Front National. As Nick Rees-Roberts 


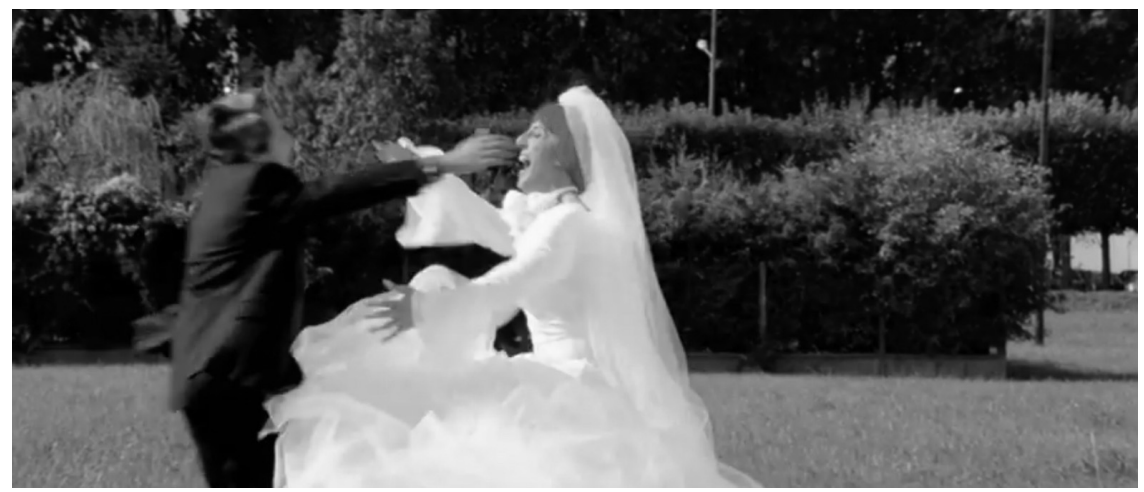

Figure 3.3 Marriage of Chouchou (Gad Elmaleh) and Stanislas (Alain Chabat) in Chouchou (2003)

Source: Chouchou (2003), directed by Merzak Allouache (c) France 2 Cinéma, Fechner Productions, KS2 Productions, and Warner Home Video France (2002).

has pointed out, when the film was released in 2003, almost six million people voted for this anti-immigration political party in the presidential election. Also worth mentioning is that at the time, Sarkozy held the post of Minister of the Interior and would later infamously take a hard line on immigration enforcement. While campaigning for president in 2006, he would also flip-flop on same-sex marriage, stating: 'I've thought long and hard about it and I'm opposed to both same-sex marriage and adoption. That's clear and precise. On the other hand, I'm deeply hostile to any form of discrimination against homosexuals' (cited in Rees-Roberts 2008: 43). While this statement could be read at best as ambivalent, at worst as discriminatory, towards queer sexualities, we do know that Sarkozy was even more hostile to immigrants. In this light, Chouchou's final scene ironically critiques any façade of a present-day French political climate wherein immigrants and gender and sexual minorities would be embraced by all.

\section{Questioning Western categorical thinking}

As both Chouchou and Fremde Haut ultimately suggest, queer migration does not equate with liberation but is instead marked by different experiences of inequality (Luibhéid 2008a; Spurlin 2016). Although acceptance of LGBTIQ+ migrants and refugees by Western countries (like Germany and France) allows for a front of acceptance, progressiveness, and safety, it simultaneously obscures an investment in neocolonial and homonationalist practices. In the context of Fremde Haut, Rachel Lewis writes that it offers a powerful critique 'of Fortress Europe's immigration and asylum policies, problematising the stereotypical queer migration narrative as that 
of a movement from "third world oppression" to "first world freedom", (Lewis 2012: 282), a statement that could also be applied to Chouchou, even if on its surface the film's message might look quite different.

In a way, this focus on homonationalism and sexual exceptionalism is perhaps the more straightforward commentary; instead, I want to push that line of thinking further to uncover what more these films provoke. For instance, while maintaining a façade of migrant acceptance and sexual exceptionalism, Fortress Europe must actually work hard to seal its borders, paradoxically pointing to the tenuousness of these literal and symbolic boundaries between nation-states and binary genders. In this, I want to ask what insights these two films offer regarding connections between migration and non-normative genders and sexualities.

From the perspective of queer diasporic and queer of colour critique, films like Fremde Haut and Chouchou enact a radical disruption of any sense of 'home' (Gopinath 2005; El-Tayeb 2011). While biopolitical, life-affirming possibilities are emphasised in Chouchou, Fremde Haut is shaped by necropolitical, death-giving forces. (The necropolitics of asylum proceedings become ever more pronounced in the film, where Fariba has actually taken on the identity of one of its casualties.) Indeed, the former concludes on an optimistic (although potentially ironic) note of integration and a sense of being 'at home', while the latter may be less hopeful, leaving us wondering what will happen to the lead character upon returning back 'home' to Iran. In decentring home as both literal (as in physical location or 'homeland') and metaphoric (as in the feeling of being 'at home' in one's body), they also destabilise gender and sexuality. While gender and sexuality are often collapsed in these films, in negotiating strict categories in their host countries - including man/woman, homosexual/heterosexual - they signal the inherent inflexibility and constraint of such labels in a Western framework, highlighting Don Romesburg's point that '[g]ender diverse queer migrants must engage in self-authoring to negotiate the multiple relations of power and desire confronting their subjectivities' (Romesburg 2013: 487). In deconstructing borders (e.g., of nation, class, and gender) and decolonising Western categories (particularly as related to gender and sexuality), they effectively trans dichotomies of active and passive within inscribed ideas of east/west or north/south and different genealogies of femininity/masculinity (Gopinath 2005: 22).

Indeed, both Fremde Haut and Chouchou point to the impossibility of applying 'Western' notions of gender and sexuality to the protagonists, particularly if they are conceived of from a particular geographical space or temporal moment that erases the ways in which gender and sexuality work (or do not work) across national and geopolitical borders. For example, while both films point to their respective characters falling outside of heteronormative economies of desire, labelling these characters as simply 'gay', 'lesbian', or 'transgender' (as some commentary on the films has done) misses the mark of examining the nuances and intricacies of overlaps between gender and 
sexuality. Just as Luibhéid has persuasively shown that these transformations 'cannot be understood within progressive, unilinear, and Eurocentric models' (Luibhéid 2008b: 170) that privilege Western notions of gender and sexuality that map to a mainstream 'LGBT' vocabulary, queer and trans function in these films not as fixed identity labels but as conceptual modes of analysis to negotiate critical spaces for self-creation and resistance within existing social structures.

\section{Conclusion: the 'transgender move' as trans potential}

The Oxford English Dictionary defines the prefix 'trans-' using an excess of prepositions: 'across, through, over, to or on the other side of, beyond, outside of, from one place, person, thing, or state to another.' Meanwhile, a second definition emphasises its transcendent potential: 'surpassing, transcending, crossing'. In reading the boundary-shifting potentiality of trans, I take a cue from transfeminist scholar A. Finn Enke's call that concepts like 'trans' open up more broadly in all directions and 'do more flexible work' (Enke 2012: 3). Similarly, Aren Aizura argues that we need a theory 'that turns "trans-" in an anti-identitarian direction', one more attentive to 'how bodies escape or act clandestinely outside those categories - and at moments in which the categories of immigrant, transgender person, man, and woman become incoherent and inconsistent' (Aizura 2012: 135). Developing a trans framework for analysing representations (cinematic and otherwise) of migration holds immense potential at this moment in which borders of all kinds - including those pertaining to gender, sexuality, citizenship, and nationality - are being simultaneously razed and fortified. Indeed, like the prefix 'trans', the noun 'transgender' is intimately and historically bound up with 'questions of nation, territory, and citizenship, with categories of belonging and exclusion, of excess and incorporation.... All current transgender phenomena are thus local and national phenomena that encounter transnationalizing forces' (Stryker and Aizura 2013: 8). In this sense, as a mode of analysis, 'trans' may grapple with the transcultural and hybrid experiences of surpassing the limits of hetero- and cisgender norms, as both Chouchou and Fariba/Siamak do, without falling into the traps of identity politics. ${ }^{6}$

Although the films are not primarily focused on transgender subjectivity, they enact what Roshanak Kheshti in her analysis of post-1990s New Iranian cinema calls 'the transgender move':

A character occupies the space of transgender potential in order to move through or survive a circumstance that s/he presumably could not otherwise. Transgender, then, figures as a space of possibility and potential. ... This transgender move presents a temporary space of political and agential potential.

(Kheshti 2009: 161-2) 
This is a space of potentiality in which, as both films showcase, the protagonists creatively craft and shape their subjectivities in new cultural spaces, engaging in a form of self-authorship that allows for new possibilities of inhabiting genders and host countries.

While the ways in which Fariba and Chouchou trans gender and borders are undoubtedly different, both are fundamentally about survival. While Chouchou reveals that she identifies as a woman, Fariba takes on a male identity because it allows her to stay in Germany. For Fariba, gaining asylum literally means being someone else, which points to the paradoxical nature of contemporary refugee and asylum proceedings. What, then, the choice to live as a man, as Siamak, means upon returning to Iran is up for discussion. Transing gender appears to be about not only survival but also mobility and openness, and both films signal ambivalent but productive possibilities as they cross borders, both visible and invisible.

I want to put forth the idea that, in the context of these two films, we take up 'transgender' - or 'trans-gender' - as a move or a movement, an analytical tool, a transgression that may overlap and intersect with other transgressions, including queer desire, undocumented migration, and illegal labour. Here, I concur with Regina Kunzel's statement that if transgender identity raises 'problems of false coherence that flattens out differences among transgender subjects, of required conformities for recognition as authentically transgender, of the implicit whiteness and middle-classness of the transgender subject - transgender analysis holds considerable promise' (Kunzel 2014: 288). Instead of thinking about transgender as an identity category, adopting it as an analytical approach allows for a theorisation and conceptualisation of its 'polymorphous transformative potential' (Kheshti 2009: 173).

Despite the divergences in their protagonists' modes of resistance and transgression, Fremde Haut and Chouchou make important contributions to enactments of trans and representations of transness. They also reflect how both hetero- and gender normativity are linked to neocolonial and neo-imperialist processes, and how the biopolitical and the necropolitical continue to exert life- and death-giving forces in border crossings and immigration enforcement. Both films collaborate with - but also subvert dominant discourses and structures around migration, immigration, and cisnormativity, as well as notions of flexible citizenship, circuits of global capital, and cosmopolitanism. In their moving beyond, surpassing, transcending, and crossing not only genders but also physical and symbolic borders and thresholds, the films' respective protagonists open up spaces of potential, possibility, and critique that, returning to the OED's definition, move 'across, through, over, to or on the other side of, beyond, outside of, from one place, person, thing, or state to another'. They enact movement across the borders of nations and the borders of gender, reshaping both gender and nation in the process. 


\section{Notes}

1 For a nuanced exploration of the category of hospitality and its representations in French and North African literature and film, see Rosello (2001).

2 Neither queer nor transgender has been immune to critique. While queer theory has been critiqued for its white, Anglo-American, elitist tendencies emerging from academic institutions, the global exportation of the discourse of transgender, including the practice of labelling longstanding cultural traditions of gender diversity under the heading of 'transgender', can be understood as an imperialist act. See also Stryker and Aizura (2013: 4).

3 Although there remains a dearth of films that have specifically addressed trans issues in relation to migration, three titles that have explored this theme are worth mentioning: Paper Dolls/Bubot Niyar (2006, Israel, dir. Tomer Heymann); The Amazing Truth About Queen Raquela (2008, Iceland/Philippines/France/Thailand, dir. Olaf de Fleur Johannesson); and Shelter: Farewell to Eden (2019, France/ Italy, dir. Enrico Masi). Interestingly, all three films feature Filipino trans migrants, but presented in very different contexts and related through different genres: Paper Dolls and Shelter: Farewell Eden are documentaries, while The Amazing Truth About Queen Raquela is a drama. It is also important to mention that in marketing material for these films, protagonists are referred to alternatively as 'trans', 'transgender', and even 'transvestite'. In the spirit of this chapter, I would argue that the films are all invested in the potential that trans holds for moving across, through, and beyond such fixed identity categories.

4 I move between the proper names Fariba and Siamak, and feminine and masculine pronouns, depending on how the character presents.

5 Because Chouchou specifically states 'I have always wanted to be a woman', I use feminine pronouns throughout, even though nearly all other scholarly readings of the film refer to Chouchou with 'he'/'him' pronouns.

6 While I take Andrea Long Chu's critique of 'transing' seriously and agree that 'verbing does not a theory make' (Chu and Drager 2019: 112), I identify potential in 'trans' as a method that reconciles the metaphor of transgender as bordercrossing with the real-life experiences of migration and crossing the borders of nation-states. 